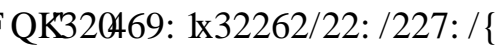

\title{
QUALITY MANAGEMENT AS A SOUND BASIS OF INTEGRATED MANAGEMENT
}

\section{QUALTITÄTSMANAGEMENT ALS GRUNDLAGE EINES INTEGRIERTEN MANAGEMENTSYSTEMS}

\author{
Beckmerhagen Ingo, Berg Heinz-Peter \\ Federal Office for Radiation Protection (Bundesamt für Strahlenschutz - BfS) \\ Willy Brandt-Str. 5, 38226 Salzgitter, Germany \\ e-mails: hberg@bfs.de
}

\begin{abstract}
Various management function-specific systems, such as for quality, environment, and occupational health and safety are described in widely applied international standards and guidelines. These documents are of obvious benefit to practising management. The implementation of a robust and effective integrated management system will support the achievement of high levels of safety performance and the enhancement and improvement of the safety culture in all types of industry. This paper has two main objectives. The first one is to address the key issues in theory and practice of integrated management systems, the second one is to illustrate the importance of an integrated (in particular safety) management system with examples from different organisations in the nuclear field.
\end{abstract}

Keywords: quality management, integrated management systems, system integration

Zusammenfassung. Verschiedene funktionsspezifische Managementsysteme, z.B. für Qualität, Umweltschutz und Arbeitsschutz, sind in weit verbreiteten internationalen Normen und Richtlinien beschrieben. Diese Dokumente werden allgemein als wertvolle Basis für die Anwendung von Managementsystemen gesehen. Die Einführung eines robusten und effektiven integrierten Managementsystems wird das Ziel unterstützen, die Sicherheit weiter zu erhöhen und die Sicherheitskultur in allen Industriebereichen zu verbessern. Das Papier hat zwei Ziele: das erste ist die Beschreibung der wesentlichen Elemente der Theorie und Praxis integrierter Managementsysteme, das zweite besteht in der Darstellung der Bedeutung eines integrierten (insbesondere Sicherheits-)Managementsystems anhand von Beispielen verschiedener Organisationen in der kerntechnischen Industrie.

Schlagworte: Qualitätsmanagement, integrierte Managementsysteme, Systemintegration 


\section{QUALITY MANAGEMENT AS A SOUND BASIS OF INTEGRATED MANAGEMENT}

\section{Introduction}

The nuclear industry has always maintained a strong focus on its quality system starting from its stringent industry standards in the 60's to a more structured and consensus-based quality assurance (QA) standards in the 80's and 90 's. The focus of the earlier development of quality programs were on the quality and safety of individual products and items. The QA based programs in the 80 's and early 90 's achieved the product quality, reliability and safety through a system approach that assured the quality of all products and items. The quality management (QM) approach in late 90 's further strengthened this focus on the quality system aspects to manage the safety and quality of products services and processes. In the last years several internationally accepted standards such as the ISO 9000 and ISO 14000 series and other function-specific management systems standards have been developed. The recent move to an integrated approach to business operations and management is elevating the quality to the next level. Although the paramount focus of nuclear industry's management system must remain on nuclear safety, environment, reliability and quality, there is general recognition that it must address other critical processes and operations that are essential for its performance and success as a business.

\section{Benefits and limits of integration of management systems}

For assessing benefits and challenges of a management system a clear understanding of the terms "management" and "system" is necessary. Managing an organisation at the various hierarchical levels of responsibilities means basically to plan, direct and control work in order to achieve set objectives optimally. Sound management that gains well defined benefits and recognises limitations, implies systematic decision making and proper procedures and work processes.

Various management function-specific systems, such as for quality, environment, and occupational health and safety are described in widely applied international standards and guidelines. These documents are of 
obvious benefit to practising management. They represent the knowledge and experience of numerous practising experts. A company does not need to start from point zero to design and implement its own most suitable system with its various processes and procedures. Quality management systems were the first introduced some years ago. Special benefits, such as improved work performance and customer satisfaction were soon normally achieved. Interest in extending to other functional areas soon increased. Issues faced by management were in the areas of environmental management and of occupational health and safety. The objectives were more effectively achieved in human, technical, financial and legal terms by means of well documented and distributed procedures. A new "process approach", that underlies all management system standards motivated not only to proceed systematically, but at the same time encouraged to suggest and improve the system performance. Internal and external audits were also expanded and became more accepted for identifying and introducing improvements.

When a quality management system preceded an environmental management system, in order to gain similar important benefits, basic design- and execution issues were similar if not identical. A general management system sets basic organisational objectives and respective general procedures and work processes. Partly existing special function management systems, such as one for quality, became integrated subsystems. This "system of systems" allows a proper co-operation of the various specialised functions and managers. Subsequent comprehensive planning and controlling in operational matters that affect every employee and business partner resolves many problems and limitations of individual function-specific systems.

System integration can:

- enhance performance and goal achievement of individual management systems,

- improve technical and technology development and transfer,

- support work and managerial co-operation and team work,

- improve inter- and intra departmental communication,

- facilitate and encourage to propose and develop improvements in processes and procedures at all levels of responsibilities,

- improve auditing at both the specialised and integrated systems,

- facilitate co-operation within an industry or community for joint development and supports to systems integration,

- improve relations with customers and suppliers,

- lead to ultimately greater operational effectiveness and efficiency. 
These various potential benefits of a system integration can be limited in reality and under the different existing and developing circumstances. As already mentioned, when a quality management system, or any other function-specific system has been already fairly successfully established in an organisation, the extensions via another system does normally not face serious problems and resistance. A gradual and sequential integration and organisation-wide harmonisation should not be too complicated, especially when external supports are available. Insufficient knowledge, understanding, and interest of the major executives and senior managers can, of course, be a major hindrance. Failure of initial measures towards integration will complicate further developments. Other typical concerns are doubts about added value of an integrated management system, perception that existing management systems are sufficient and should remain or the possibility that audits may still be performed separately, even though the systems are integrated into a single entity. Therefore, any system integration should be approached with utmost care. However, the implementation of a robust and effective integrated management system will support the enhancement and improvement of the safety culture and the achievement of high levels of safety performance in all types of industry.

\section{Examples of approaches in the nuclear field}

\subsection{Integrated safety management system of the US Department of Energy}

The United States Department of Energy (USDOE) is the government's leading science and technology agency whose research and activities support the U.S. energy security, national security, and environmental quality. Its mandate includes maintaining the safety and reliability of the U.S. nuclear stockpile and restoration of the environment from the legacy of the Cold War. It is also a primary source of nuclear based research and applications such as neutron and particle physics and isotope production for both commercial and medical application. Thousands of people are employed at numerous sites across U.S., all being vulnerable to various types and degrees of hazards at their workplace. Some hazards are large enough to be of potential risk to the general public. Chemical, radiation, criticality, industrial, and construction hazards are part of a wide range of safety concerns which must be addressed in a structured and consistent manner. In the past, the extensive variety of USDOE facilities, missions, and responsibilities resulted in difficulty in defining a reasonable "acrossthe-board" method for the evaluation and implementation on safety. 
Consequently, the search continued to find a safety methodology that was sufficiently prescriptive and consistent to allow USDOE to perform its job of oversight but still allow sufficient contractor flexibility such that high standards for safety evaluations could be met consistently and in a costeffective and relevant manner resulting in USDOE Integrated Safety Management (ISM) system.

The USDOE embraces the ISM system philosophy and has issued a policy document which consists of six hierarchical components that provide guidance and requirements to the department and its contractors for achieving the "objective" of systematically integrating safety into management and work practices at all levels. The first three components of the Doe ISM policy (objective, guiding principles, and core functions) are to be consistently applied at all DOE facilities. Component 2 identifies seven "guiding principles" that are to be followed while applying the other components of ISM. Component 3 provides five safety management core functions as the steps that must be taken to attain the ISM "objective" of integrated safety. The five core safety management functions provide the necessary structure for any work activity that could potentially affect the public, the workers, and the environment. Core functions are applied as a continuous cycle with the degree of rigor appropriate to address the type of work activity and the hazard involved. The other three components of the ISM system (mechanisms, responsibilities, and implementation) are established by the DOE contractors for the work they perform and vary based on the nature and hazards of the specific activity.

\subsection{Integrated performance based management system of AECL}

The management system approach to quality management requires that all key aspects for the successful operations of the nuclear business must be considered and managed to achieve its established mandate and objectives. The current global environment and competitive leverage for survival requires that the management system must achieve the required business performance and results to meet the expectations of all its key stakeholders and the regular body. The Integrated Performance Based Management System (IPBMS) as described in this section provides an approach to meet these objectives. It integrates all technical, operational and commercial processes of the organisation including regulatory, technology, safety, environment, human resources, finance, marketing, etc. The IPBMS goes beyond the compliance model and it focuses on the performance and end 
results along with the interrelated processes and the system aspects. The IPBMS is a evolution for nuclear organisations that have successfully mastered the compliance-based management system. Some of the IPBMS elements and principles are adapted at the Atomic Energy of Canada Limited (AECL) as shown in Figure 1.

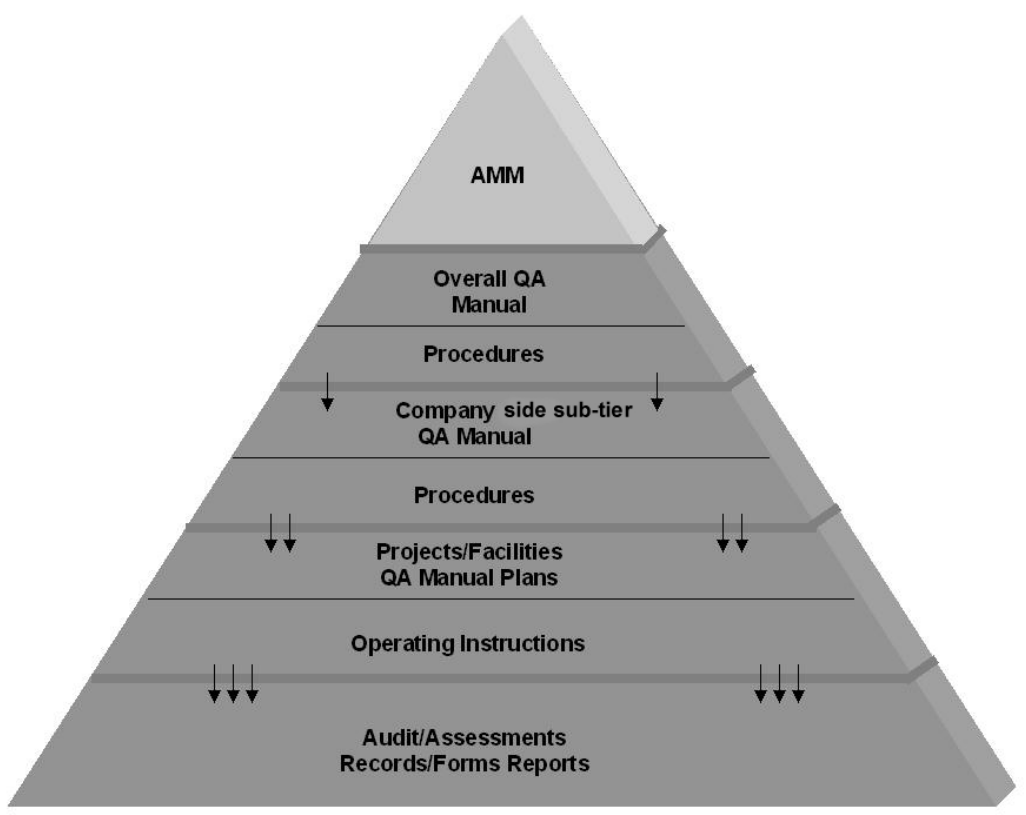

Fig. 1. AECL Management System Hierarchy

The top level management manual called AECL Management Manual (AMM) covers:

- An overview of the corporation and its mandate and vision, including its values, principles and policies that guide the Corporation's conduct.

- A description of the organisational structure and the mandate of the various organisational units.

- An overview of business process management, compliance management and review at AECL.

- A listing of, and management responsibility for, products and services provided to external customers, supporting and evolving technologies, business and strategic initiatives, business processes, requirements upon AECL, and sites, facilities and offices that are managed by AECL. 
In addition to the AMM, AECL has a set of QA Manuals under the Overall QA Manual (see Figure 1) covering the various nuclear life cycle programs (R\&D, design, software, etc.) and other program manuals (environmental protection, hazardous material, emergency preparedness, etc.).

\subsection{Management system of the Federal Office for Radiation Protection}

BfS elaborates professional scientific recommendations for the Federal Ministry for the Environment, Nature Conservation and Nuclear Safety (BMU) and supports BMU in its development of legal regulations in nuclear safety and radiation protection. The processes included in the BfS QM manual were identified by the products contained in a cost accounting and results account system. The approach follows the process oriented procedure of DIN EN ISO 9001:2000 as shown in Figure 2.

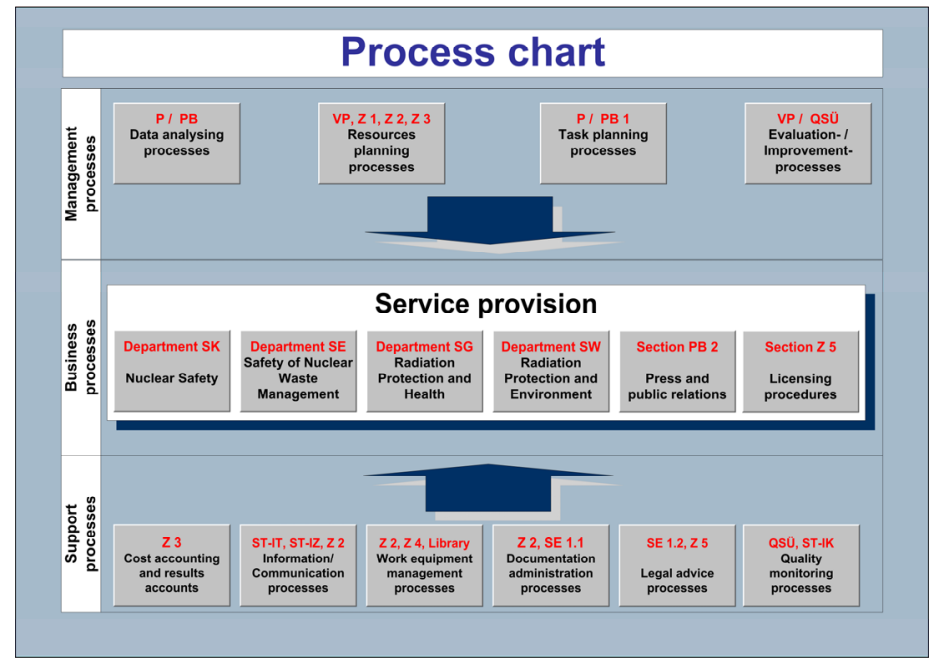

Fig. 2. Process chart

The QM manual provides mainly a guidance to the general ordinance and instructions (work equipment/instruction documents) of BfS.

The upper level of hierarchy of any authority document (cf. Figure 3) consists of the general ordinance (GO) regulating the general procedural organisation and the general office operations as well as the structural organisation and the schedule of responsibilities. The second level contains instructions. WHO?, WHAT?, WHEN? and HOW? are laid down in these instructions. These instructions apply to all employees and are issued by the BfS management. In the third level all other work instructions have been 
comprised including special manuals such as the calibrating laboratory QM manual (needed for a certification of this activity. As specification document work instructions generally apply to only one organisational unit and are basically brought into force by the respective head of the unit.

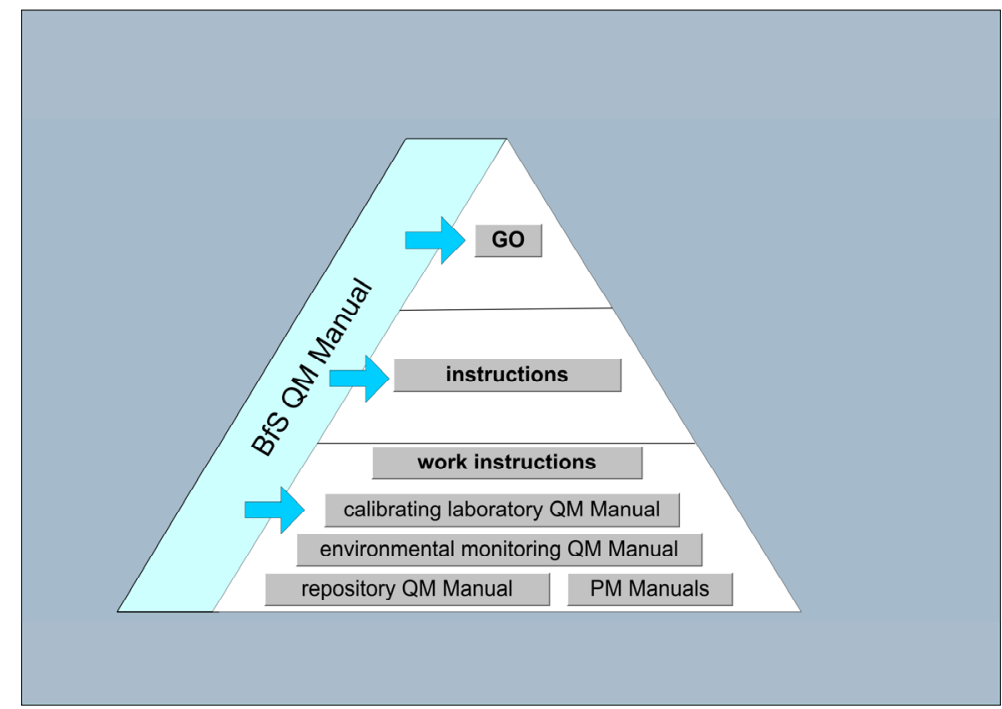

Fig. 3. Documentation structure

\section{Concluding remarks}

Modern organisations integrate management systems that address all their objectives through the definition of a single framework of arrangements and processes. These objectives include safety, health, quality and often economic, social responsibility and other considerations. The definition of the organisations' processes forms the background of its management system. The examples presented in this paper showed that the integration of different systems is a gradual effort and that the sequence of internal systems to be covered depends on many factors, including the industry section and organisational strategy. In the nuclear industry, the first step may involve the harmonisation and amalgamation of safety, quality and environment management frameworks. The examples provided have one common approach: the structure of the integrated management systems was built up in such a way that management systems not yet integrated or systems planned to be developed and implemented in future can easily be added in an integrative manner. 


\section{QUALTITÄTSMANAGEMENT ALS GRUNDLAGE EINES INTEGRIERTEN MANAGEMENTSYSTEMS}

\section{Einleitung}

Die kerntechnische Industrie hat immer ein großes Augenmerk auf Qualität gelegt, von stringenten Industrienormen in den 60iger Jahren $\mathrm{zu}$ mehr strukturierten und konsensbasierten Qualitätssicherungs (QS)-Standards in den 80iger und 90iger Jahren. Schwerpunkte der früheren Entwicklungen des Qualitätsprogramms waren die Qualität und Sicherheit einzelner Produkte. Die QS-basierten Programme in den 80igern und frühen 90iger Jahren erreichten Produktqualität, Zuverlässigkeit und Sicherheit durch einen Systemansatz, der die Qualität aller Produkte gewährleistete. Der Qualitätsmanagement (QM)-Ansatz in den späten 90iger Jahren war auf QSAspekte fokussiert, um die Sicherheit und Qualität von Produktprozessen zu managen. In den letzten Jahren wurden verschiedene, international akzeptierte Normen wie z.B. die ISO 9000 - und ISO 14000 - Serien und andere funktionsspezifische Standards für Managementsysteme entwickelt. Dabei hat eine Verschiebung zu einem integrierten Ansatz auch das Qualitätsmanagement auf ein anderes Niveau gehoben. Auch wenn der zentrale Punkt des Managementsystems in der Kerntechnik die nukleare Sicherheit, der Umweltschutz, die Zuverlässigkeit und Qualität der Sicherheitssysteme bleibt, ist es allgemein anerkannt, dass ein integriertes Managementsystem auch andere kritische Prozesse abdecken muss, die für einen erfolgreichen Betrieb erforderlich sind.

\section{Vorteile und Grenzen der Integration von Managementsystemen}

Um die Vor- und Nachteile eines Managementsystems bewerten zu können, ist ein klares Verständnis der Begriffe „Management“ und „System“ notwendig. Das Management einer Organisation in den verschiedenen Hierarchie- und Verantwortlichkeits-Ebenen bedeutet grundsätzlich, die Arbeiten so zu planen, durchzuführen und zu kontrollieren, um die festgelegten Ziele optimal zu erreichen. Ein Management, das Vorteile definiert und Grenzen berücksichtigt, impliziert systematische Entscheidungen und führt zu geeigneten Prozeduren und Arbeitsprozessen. 
Verschiedene funktionsspezifische Managementsysteme, z.B. für Qualität und Arbeitsschutz, sind in weit verbreiteten internationalen Normen und Richtlinien beschrieben. Diese Dokumente werden allgemein als wertvolle Basis für die Anwendung von Managementsystemen gesehen, weil sie die praktischen Erfahrungen vieler Experten widerspiegeln. Ein Unternehmen muss nicht von Null beginnen, um sein eigenes, auf seine Bedürfnisse zugeschnittenes System mit seinen verschiedenen Prozessen und Prozeduren einzuführen. Qualitätsmanagementsysteme waren die ersten, die vor einigen Jahren implementiert und mit denen Ziele wie z.B. Kundenzufriedenheit erreicht wurden. Das Interesse, QM auf andere Gebiete auszudehnen, hatte als Ziel, technische, finanzielle und rechtliche Aspekte effektiver durch gut dokumentierte Prozeduren zu berücksichtigen. Ein neuer „Prozessansatz“, der allen Normen zu Managementsystemen zugrunde liegt, motiviert nicht nur $\mathrm{zu}$ einer systematische Umsetzung, sondern fördert auch die Verbesserung des vorhandenen Systemkonzepts. Interne und externe Audits werden ebenfalls erweitert und immer mehr als Instrument zur Identifizierung und Einführung von Verbesserungen angesehen.

Wenn ein Qualitätsmanagementsystem z. B. bereits vor der Einführung eines Umweltschutzmanagementsystems existiert, sind die grundsätzlichen Themen ähnlich, wenn nicht identisch, um vergleichbare bedeutende Vorteile $\mathrm{zu}$ gewinnen. Ein allgemeines Managementsystem setzt grundlegende Organisationsziele und entsprechende allgemeine Prozeduren und Arbeitsprozesse voraus. Teilweise existierende funktionsspezifische Managementsysteme, z.B. für Qualität, werden integrierte Untersysteme. Dieses „System der Systeme“ erlaubt eine gute Kooperation der verschiedenen spezialisierten Funktionen und Manager. Daraus abgeleitete, umfangreiche Planungen und Kontrollen, die jeden Mitarbeiter und Geschäftspartner betreffen, lösen viele Probleme und heben Begrenzungen der individuellen funktionsspezifischen Systeme auf.

Systemintegration kann:

- die Zielerreichung im Vergleich zu einzelnen Managementsystemen erhöhen und insgesamt zu einer höheren Effektivität führen,

- technische Weiterentwicklungen und Technologietransfer verbessern,

- die Zusammenarbeit zwischen Arbeits- und Managementebene sowie Teamarbeit unterstützen,

- die Kommunikation zwischen Organisationseinheiten verbessern, 
- einen Anstoß geben, Verbesserungen von Prozessen und Prozeduren in allen Verantwortungsbereichen zu entwickeln,

- Audits für spezielle, aber auch für integrierte Systeme verbessern,

- die Zusammenarbeit innerhalb der Industrie für gemeinsame Aktivitäten fördern,

- die Beziehungen zwischen Kunden und Zulieferern verbessern.

Diese verschiedenen möglichen Vorteile einer Systemintegration können in der Praxis und existierenden betrieblichen Gegebenheiten eingeschränkt werden. Wenn, wie bereits vorher erläutert, ein QM-System oder ein anders funktionierendes System bereits erfolgreich in einer Organisation eingeführt wurde, führen die Erweiterungen auf ein anderes System normalerweise nicht $\mathrm{zu}$ ernsthaften Problemen und Widerständen. Eine schrittweise Einführung und organisationsweite Harmonisierung sollte nicht sehr kompliziert sein, insbesondere wenn externe Unterstützung vorhanden ist. Ungenügende Kenntnis, kein Verständnis und kein Interesse der entscheidungsbefugten Manager können ein großes Hindernis sein. Fehler bei den ersten Maßnahmen zur Integration werden weitere Entwicklungen erschweren. Andere typische Bedenken sind Zweifel über den zusätzlichen Gewinn eines integrierten Managementsystems, die Annahme, dass die existierenden Managementsysteme ausreichend sind und erhalten bleiben sollen oder die Möglichkeit, dass die Audits weiterhin separat durchgeführt werden können, auch wenn die Systeme bereits in ein einziges System integriert sind. Daher muss jede Integration sehr umsichtig angegangen werden. Insgesamt wird aber die Einführung eines robusten und effektiven integrierten Managementsystems die Verbesserung der Sicherheitskultur in allen Industriezweigen verbessern.

\section{Beispiele aus dem kerntechnischen Bereich}

\subsection{Integriertes Sicherheitsmanagementsystem der amerikanischen Behörde DOE}

Die amerikanische Energiebehörde (USDOE) ist eine staatliche Behörde, die Forschungen und Aktivitäten auf dem Gebiet der Energiesicherheit und des Umweltschutzes durchführt. Die Aufgabe dieser Behörde umfasst auch die Sicherheit und Zuverlässigkeit der amerikanischen nuklearen staatlichen Anlagen, die Wiederherstellung der Umgebung von Hinterlassenschaften des kalten Krieges sowie Forschung und Anwendungen (z. B. der Neutronen- und Teilchenphysik und die Isotopenproduktion sowohl für kommerzielle als auch für medizinische Zwecke). Tausende von 
Mitarbeitern arbeiten in vielen Institutionen in den verschiedenen Staaten der USA, die alle verschiedenen Gefährdungen an ihren Arbeitsplätzen ausgesetzt sind. Einige Gefährdungen können auch Auswirkungen auf die Bevölkerung haben. Solche sicherheitsrelevanten Aktivitäten müssen in strukturierter und konsistenter Weise behandelt werden. In der Vergangenheit führten die sehr unterschiedlichen USDOE Institute sowie Aufgaben und Verantwortungsbereiche zu Schwierigkeiten, eine übergreifende Methode zur Bewertung und Implementierung eines Sicherheitskonzeptes zu definieren. Daher wurde eine sicherheitsgerichtete, konsistente Methode gesucht, die es USDOE erlaubt, ihre Aufsichtstätigkeit auszuüben, aber trotzdem ausreichend Flexibilität für die zahlreichen Auftragnehmer ermöglicht. Dies führte letztendlich zum USDOE integrierten Managementsystem (IMS). Dazu hat USDOE ein PolicyDokument herausgegeben, das aus sechs hierarchischen Komponenten besteht, mit denen Leitlinien und Anforderungen an die Organisationseinheit und seine Auftragnehmer zur Erreichung des Ziels einer systematischen Integration des Sicherheitsgedankens auf allen Ebenen bereitgestellt werden. Die ersten drei Komponenten des Policy-Dokuments (Ziele, Leitlinien, Kernfunktionen) müssen konsistent in allen DOEAnlagen angewandt werden. Die Leitlinien identifizieren sieben Prinzipien, die eingehalten werden müssen, wenn die anderen Komponenten des IMS angewendet werden. Komponente 3 definiert fünf Kernfunktionen des Sicherheitsmanagements, die eingehalten werden müssen, um das IMS-Ziel des integrierten Sicherheitskonzepts zu erreichen. Diese Kernfunktionen bilden die notwendige Struktur für jede Aktivität, die möglicherweise die Öffentlichkeit, die Arbeiter und die Umwelt betreffen, und werden im Rahmen eines kontinuierlichen Prozesses angewandt. Die drei anderen Komponenten des IMS (Prozedur, Verantwortungsbereiche und Implementierung) gelten für die DOE-Auftragnehmer und variieren in Abhängigkeit vom jeweiligen Gefährdungsgrad der spezifischen Aktivität.

\subsection{Integriertes Managementsystem von AECL}

Der Ansatz eines integrierten Managementsystems erfordert die Einbeziehung aller wesentlichen Aspekte für einen erfolgreichen Betriebsablauf, um die vorgegebenen Ziele der Stakeholder sowie der Behörde zu erreichen, und umfasst daher alle technischen, betrieblichen und kommerziellen Prozesse der Organisation. Einige Elemente und Prinzipien wurden von der kanadischen Gesellschaft Atomic Energy of Canada Ltd (AECL), wie in Abb. 1 dargestellt, adaptiert. 


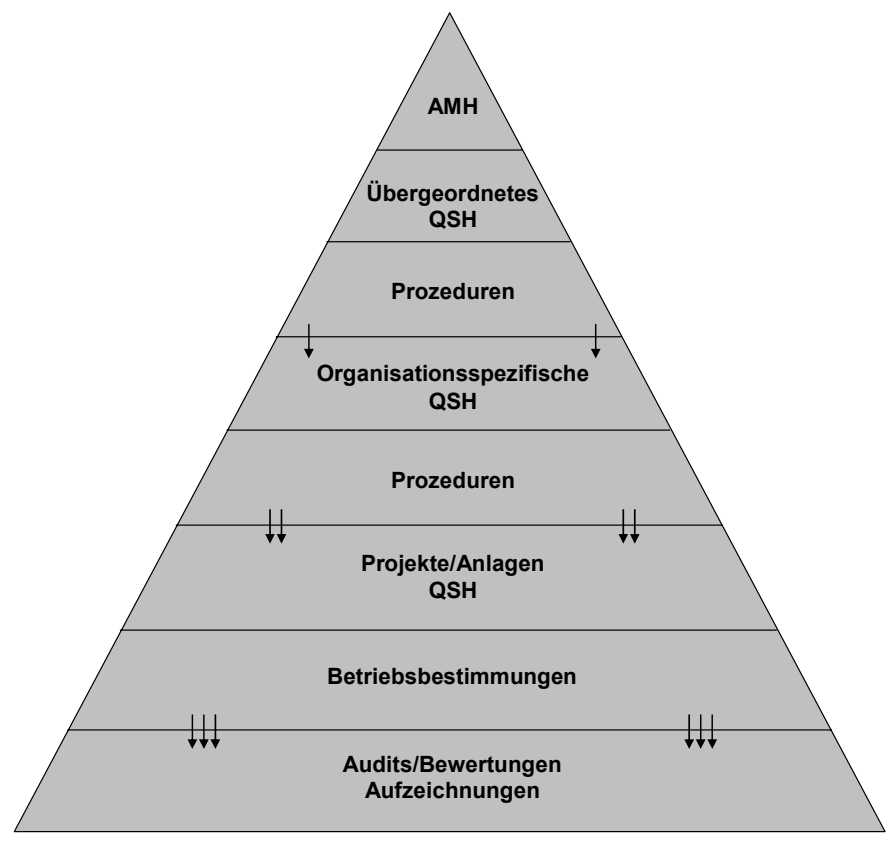

Abb. 1. Hierarchie des Managementsystems

Das oberste Dokument in der Hierarchie des Managementsystems ist das sogenannte AECL-Managementhandbuch (AMH) und umfasst

- einen Überblick über die Firmen, ihr Mandat, ihre Visionen und Werte sowie die Prinzipien und der Politik des Unternehmens,

- die Organisationsstruktur und Verantwortlichkeiten,

- das übergeordnete Managementsystem und seine Überprüfung,

- die Managementverantwortlichkeiten für Produkte und ServiceAktivitäten für externe Kunden sowie Standorte und Anlagen, die von AECL gemanagt werden.

Das AMH wird ergänzt durch eine Serie von QS-Handbüchern, die im übergeordneten QSH zusammengeführt werden und die die verschiedenen kerntechnischen Lebenszyklusprogramme (Forschung, Auslegung, Software etc.) und spezielle QSH zum Umwelt- oder Katastrophenschutz umfassen.

\subsection{Managementsystem des Bundesamtes für Strahlenschutz (BfS)}

Das BfS erarbeitet wissenschaftliche Empfehlungen für das Bundesministerium für Umwelt, Naturschutz und Reaktorsicherheit (BMU) und unterstützt das BMU bei der Weiterentwicklung des Regelwerkes auf 
den Gebieten der kerntechnischen Sicherheit und des Strahlenschutzes. Die Prozesse im BfS-QMH wurden mit Hilfe der Produkte identifiziert, die in der Kosten- und Leistungs-Rechnung enthalten sind. Dieser Ansatz folgt dem prozessorientierten Ansatz der DIN EN ISO 9001:2000 (Abb. 2).

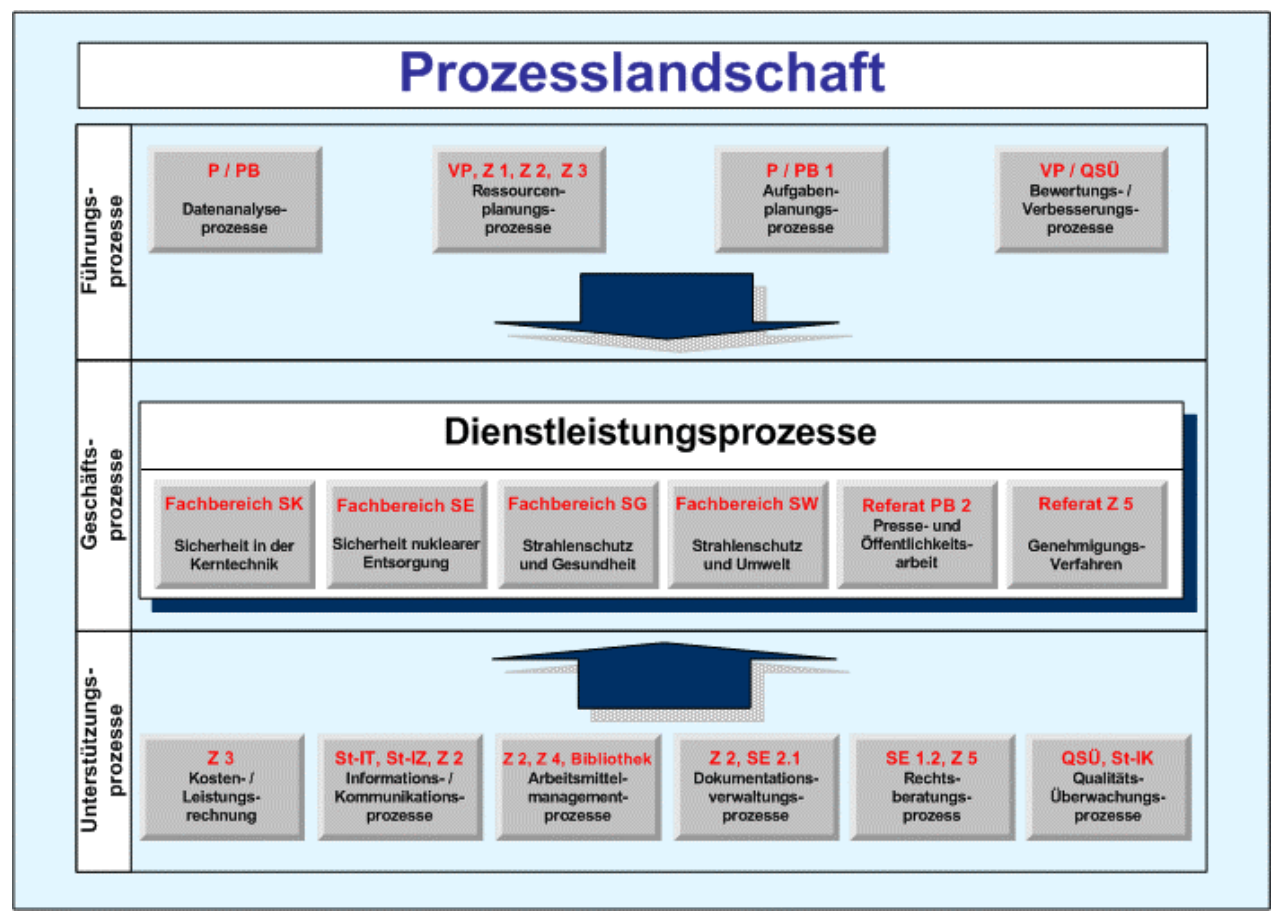

Abb. 2. Prozesslandschaft

Das QM-Handbuch ist in erster Linie Wegweiser zu den Vorschriften und Anweisungen (Arbeitsmitteln/Vorgabedokumenten) des BfS. Die oberste Ebene der Hierarchie der Dokumente bei einer Behörde (siehe Abb. 3) besteht aus der Geschäftsordnung (GO), die den allgemeinen Geschäftsgang (Ablauforganisation) und den allgemeinen Dienstbetrieb regelt, sowie dem Organigramm (Aufbauorganisation) und dem Geschäftsverteilungsplan. In der zweiten Ebene sind Dienstanweisungen dargelegt, in denen das WAS?, das WANN? und das WIE? festgelegt sind und die amtübergreifend gelten und von der Amtsleitung herausgegeben werden. In der dritten Ebene sind alle übrigen Arbeitsanweisungen zusammengefasst; sie gelten in der Regel für einen Fachbereich und/oder dessen Organisationseinheiten und werden grundsätzlich vom jeweiligen Vorgesetzten in Kraft gesetzt. 


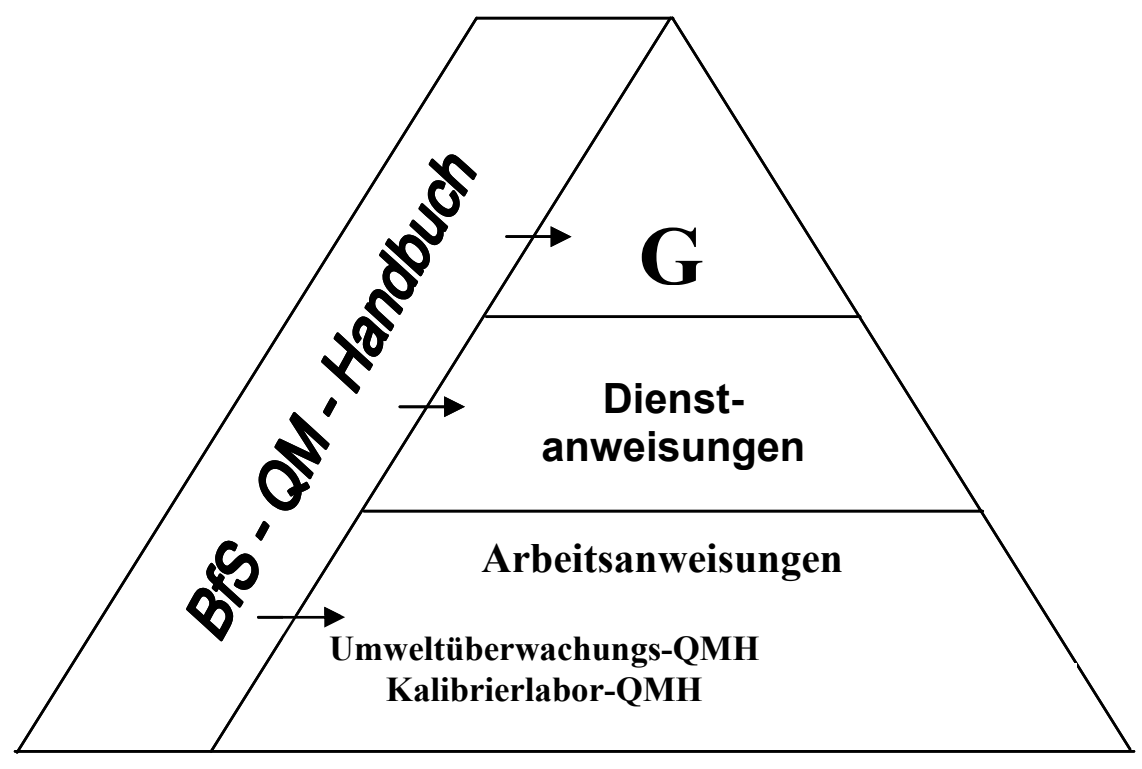

Abb. 3. Dokumentenstruktur

\section{Abschließende Bemerkungen}

Moderne Organisationen integrieren Managementsysteme, die alle Ziele durch die Definition eines einzigen Rahmens für die notwendigen Prozesse enthalten. Diese Ziele umfassen Sicherheit, Arbeitsschutz und Qualität und in vielen Fällen auch ökonomische und soziale Verantwortung. Die Definition der Organisationsprozesse bildet den Hintergrund des Managementsystems. Die Beispiele in diesem Papier zeigen, dass die Integration verschiedener Systeme ein gradueller Erfolg ist und dass die internen Systeme, die berücksichtigt werden müssen, von vielen Faktoren, einschließlich der Organisationsstrategie, abhängen. In der kerntechnischen Industrie wird der erste Schritt die Harmonisierung und Zusammenlegung der separat existierenden Managementsysteme zu Sicherheit, Qualität und Umwelt sein. Die beschriebenen Beispiele haben einen gemeinsamen Ansatz: die Struktur der integrierten Managementsysteme wurde so gestaltet, dass Managementsysteme, die noch nicht integriert oder in Planung sind und später implementiert werden sollen, problemlos eingefügt werden können. 
